\title{
Фавелы, геджеконду, «нахаловки»: сквоттерские поселения в городах развивающихся и постсоветских стран ${ }^{1}$
}

\author{
Н.И. КАРБАИНОВ*
}

\begin{abstract}
*Николай Иванович Карбаинов - научный сотрудник, Социологический институт ФНИСЦ РАН. Адрес: 190005, Санкт-Петербург, ул. 7-я Красноармейская, д. 25/14. E-mail: nkarbainov@gmail.com

Цитирование: Карбаинов Н.И. (2018) Фавелы, геджеконду, «нахаловки»: сквоттерские поселения в городах развивающихся и постсоветских стран // Мир России. Т. 27. № 1. C. 135-158. DOI: 10.17323/1811-038X-2018-27-1-135-158
\end{abstract}

В данной статье проанализированы ключевые концепции и темы исследований по проблеме сквоттерских поселений в городах развивающихся и постсоветских стран (в том числе в российских городах). По результатам анализа литературы выделень три этапа в изучении сквоттерских поселений в развивающихся странах: (1) 1950-е - первая половина 1960-х г2. - период господства теорий модернизации; (2) вторая половина 1960-х - 1970-е г2. - период «демифологизации» и романтизащии сквоттерских поселений; (3) 1980-е г2. - по настоящее время - период концептуального плюрализма. Исследования в сквоттерских поселениях в постсоветских городах стали проводится только с 1990-х г2., но, несмотря на это обстоятельство, по своим используемым кониепциям, результатам и выводам они вполне сопоставимы с исследованиями, проводимыми в развивающихся странах. В статье выделены четыре ключевые темы в исследованиях постсоветских неформальных поселений: (1) стратегии обретения недвижимости в самовольных поселениях; (2) проблема взаимоотношений жителей неформальных поселений с коренными горожанами; (3) стратегии сочиально-экономической адаптащии мигрантов, проживающих 8 сквоттерских поселениях; (4) отношения жителей неформальных поселений с государственными институтами и другими политическими акторами.

Ключевые слова: сквоттерские поселения, неформальные поселения, сельские мигранты, урбанизация, сельско-городская миграция, постсоветский город

1 Статья написана при финансовой поддержке РФФИ в рамках проекта «Институт захватного землепользования на Востоке России: исторический и сравнительный анализ» (№ 16-32-00029). 
Сквоттерские поселения являются широко распространенным феноменом, и в первую очередь в городах третьего мира - favelas в Бразилии, gecekondu в Турции, barong-barong на Филиппинах и т.д. Тем не менее эти поселения характерны не только для городов развивающихся стран, но распространены и в постсоциалистических странах, в том числе в государствах бывшего CCCP [Tsenkova, Potsiou, Badyina 2009] - «нахаловки», «самоволки», «самострои», «новостройки» или «нахалстрои». Саша Ценкова рассматривает сквоттерские поселения как один из типов неформального жилья [Tsenkova 2012] ${ }^{2}$. Несмотря на ряд региональных особенностей, они имеют и ряд общих признаков: (1) значительную часть их населения составляют сельские мигранты (но не всегда!); (2) там живут преимущественно бедняки (но не обязательно!); (3) для них характерна некоторая степень нелегальности (самозахват земли, находящейся в государственной или частной собственности, нарушение градостроительных норм и т.д.).

Цель данной статьи - осветить ключевые концепции и темы исследований, посвященные проблеме сквоттерских поселений, как в развивающихся странах, так и в странах бывшего СССР. В изучении этого феномена в развивающихся странах на основе анализа литературы можно выделить три этапа: (1) 1950-е - первая половина 1960-х гг. - период господства теорий модернизации; (2) вторая половина 1960-х - 1970-е гг. - период демифологизации и романтизации сквоттерских поселений; (3) 1980-е гг. - настоящее время - период концептуального плюрализма. Сквоттерские поселения в постсоветских городах стали объектом исследования начиная только с 1990-х гг. В отличие от сквоттерских поселений в городах третьего мира, неформальные поселения в постсоветском пространстве (в том числе и в российских городах) остаются относительно малоизученным явлением. Тем не менее мы покажем, что подобные исследования уже успешно проводятся и обращают на себя внимание зарубежных коллег.

\section{Период господства теорий модернизации (1950-е - первая половина 1960-х гг.)}

Начало всемирной интенсивной урбанизации в 1950-1960-е гг. совпало с периодом доминирования в социальных науках теорий модернизации, которые в значительной степени повлияли на первых исследователей феномена сквоттерских поселений в странах Латинской Америки и Турции [Cornelius 1977; Erman 2001; Demirtaş 2009]. Можно выделить три основные точки зрения на эту проблематику, сформировавшиеся под влиянием теории модернизации: (1) сквоттерские поселения как «транзитные зоны»; (2) неформальные поселения как источник социальных болезней и преступности, социальной и личностной дезорганизации; (3) неформальные поселения как «сельские анклавы» в городе.

\footnotetext{
2 Наряду со сквоттерскими поселениями на частной и общественной земле С. Ценкова выделяет следующие типы неформальных поселений: поселения беженцев и других уязвимых групп населения; улучшенные сквоттерские поселения; поселения, расположенные на незаконно разделенных пригородных земельных участках [Tsenkova 2012]. В нашей статье мы будем использовать понятия «сквоттерские поселения» и «неформальные поселения» как синонимы, но при этом четко понимая, что помимо сквоттерских поселений существуют другие типы неформального жилья.
} 
Точка зрения о неформальных поселениях в качестве «транзитных зон» сформировалась под влиянием концепции модернизации стран третьего мира. Согласно этому взгляду, значительная часть сельских мигрантов, попав в город, проживают в сквоттерских поселениях, а позже должны переселиться в более привлекательные благополучные районы. В этом случае сквоттерские поселения были преимущественно первым местом пребывания в городе для сельских мигрантов [Costello 1987, р. 428]. Они выступали «транзитными зонами» не только в пространственном измерении, но и в социокультурном смысле: сельские мигранты должны со временем превратиться в горожан, а сквоттерские поселения, которые рассматривались как временный исторический феномен, должны были исчезнуть в процессе модернизации стран третьего мира: так, в 1950-1960-е гг. первые исследователи геджеконду (турецких неформальных поселений), которые находились под сильным влиянием теории модернизации, пытались объяснить возникновение этих поселений и их интеграции в модерновые/городские структуры [Erman 2001, p. 989].

Вторая точка зрения о неформальных поселениях как источнике социальных болезней, преступности, личностной и социальной дезорганизации во многом сформировалась под влиянием концепции урбанизма Л. Вирта, концепции «культуры бедности» О. Льюиса и теории маргинальности. Опираясь на эти концепции, исследователи рассматривали трущобы в центральных районах и сквоттерские поселения на окраинах городов развивающихся стран как пространства «отсталости», «культуры бедности» и маргинальности. В тоже время среди сторонников данной точки зрения существовали разногласия по поводу проблемы экономической и политической инкорпорации жителей неформальных поселений. Одна группа ученых считала, что жители неформальных поселений не интегрированы в экономическую и политическую жизнь своих стран и принимают минимальное участие в политике; эти исследователи настаивали на аполитичности сквоттеров [Lloyd 1979, p. 186]. Другая группа, наоборот, считала, что социальная дезорганизация и личностная фрустрация сельских мигрантов, пополняющих ряды городской бедноты, приводят к их радикализации и поддержке политического экстремизма [Peattie, Aldrete-Haas 1981, pp. 162-163].

Сторонники третьей точки зрения, находившиеся под влиянием идей концепций псевдоурбанизации или рурализации города, исходили из того, что неформальные поселения - это сельские анклавы, в которых воспроизводятся практики и нормы деревенского общежития в агрессивном городском окружении [Lomnitz 1977, p. 8]. Структурно эти анклавы часто рассматривались как суррогаты или копии сельского социального порядка. Миграция в город в данном случае являлась просто физическим перемещением сельских мигрантов из стабильного сельского социокультурного окружения в стабильную городскую социокультурную среду [Snyder 1976, p. 36]. При этом сельские анклавы воспринимались как замкнутые единицы, слабосвязанные с окружающим городским сообществом. Неслучайно методология в социологических и антропологических исследованиях аккультурации сквоттеров часто выводилась из предыдущих этнографических исследований сельских сообществ и аборигенных племен [Perlman 1976, p. 66]. Согласно этим взглядам, многие сельские мигранты не ассимилировались в процессе урбанизации, а вместо этого концентрировались в сквоттерских поселениях, сохраняя многие ценности крестьянского мира: фатализм, религиозность, слабую восприимчивость к инновациям, почтение к фигурам традиционной власти и т.д. [Peattie, Aldrete-Haas 1981, p. 162]. 


\section{Период демифологизации и романтизации сквоттерских поселений (вторая половина 1960-х - 1970-е гг.)}

Во второй половине 1960-х и в 1970-е гг. конвенциональный модернизационный подход был раскритикован двумя другими (конкурирующими друг с другом) методиками - марксистской и либеральной [Hushzermeyer 2004, pp. 7-8]. Сторонники марксистского подхода, анализируя в первую очередь противоречия капиталистического способа производства, понимали проблему неформальных поселений как выражение эксплуатации со стороны господствующих капиталистических классов. В марксистских исследованиях подчеркивалась роль социальной мобилизации как средства, стимулирующего фундаментальные социальные изменения, которые приведут к краху капиталистической системы. С этой точки зрения политика облегчения материальных условий в неформальных поселениях, например, с помощью улучшения инфраструктуры, подвергалась критике за сохранение status quo. Сторонники либерального подхода, в свою очередь, принимали как данность капиталистическую систему и присущую ей эксплуатацию, приводящую к постоянному возникновению неформальных поселений. Их исследования сквоттерских поселений были направлены не на поиск фундаментальных вызовов существующей общественной системе, а на уменьшение последствий эксплуатации. Ученые-либералы пытались понять, с помощью каких механизмов жители неформальных поселений выживают на свои минимальные средства. В 1960-х гг. такие исследования привели к тому, что начали высказываться мнения, что конвенциональная на тот момент политика сноса сквоттерских поселений наносила больше вреда, чем пользы [Hushzermeyer 2004, pp. 7-8].

Первые работы, основывающиеся на либеральном подходе к проблеме неформальных поселений, появились еще вначале 1960-х гг.: так, в одной из публикаций Чарльз Стокс предложил следующую классификацию трущоб: «трущобы безысходности» (slums of despair) и «трущобы надежды» (slums of hope) [Stokes 1962]. По мнению Ч. Стокса, территориально «трущобы безысходности» в основном расположены в центральных городских районах и населены бедняками-арендаторами, а «трущобы надежды» - на городских окраинах и населены людьми, которые самостоятельно построили свое жилье. Если для жителей «трущоб безысходности» характерны апатия, пассивность, дезорганизация и отсутствие перспектив, то населявшие «трущоб надежды» люди экономически и социально активны и с уверенностью смотрят в будущее [Stokes 1962]. Ч. Стокс считал, что «трущобы безысходности» не исчезнут, т.к. там проживает городская беднота, а «трущобы надежды» - это временный дом для мигрантов и своеобразная школа жизни, и они исчезнут после того, как сократится поток миграции [Stokes 1962, p. 191].

Наибольшее влияние на изменение исследовательской повестки дня и подрыв взглядов конвенционального подхода в изучении неформальных поселений и романтизации сквоттеров оказали работы американского антрополога У. Мэнжина и британского архитектора Дж. Тернера. В 1950-1960-е гг. У. Мэнжин проводил этнографические исследования в сквоттерских поселениях (barriadas) столицы Перу, Лиме. Опираясь на собственные полевые данные и результаты исследований коллег в других латиноамериканских городах, он попытался развеять существующие мифы в отношении неформальных поселений, выделив следующие из них: 
- сквоттерские поселения создаются сельскими мигрантами, которые прибывают напрямую из сельской местности;

- эти поселения хаотичные и неорганизованные;

- сквоттерские поселения - трущобы с присущими им преступностью, проституцией, разрушением семейных отношений и т.д.;

- жители этих поселений не приносят пользы национальным экономикам изза высокого уровня безработицы, их труд лучше использовать в сельском хозяйстве;

- они не участвуют в жизни города, для них характерны высокий уровень неграмотности и низкий уровень образования;

- сквоттерские поселения представляют собой рассадники радикальной политической активности;

- они являют собой деревни (или индейские сообщества), воспроизводимые в городе;

- существуют два способа решения этой проблемы: а) с помощью законов препятствовать миграции или делать жизнь в провинции более привлекательной, или б) противодействовать созданию новых сквоттерских поселений, сносить уже существующие, заменяя их запланированным жильем [Mangin 1967, p. 66]. Другой влиятельный сторонник либерального подхода Дж. Тернер рассматривал сквоттерские поселения не как социальную проблему, а как способ решения этой проблемы [Turner 1968]. Ключевая мысль в работах Дж. Тернера - идея самопомощи (self-help) - заключается в том, что жители должны самостоятельно решать, каким образом им строить собственное жилье, а задача государства состоит в помощи им в этом деле. Роль государства в этом процессе должна сводиться к планированию и обеспечению доступа к инфраструктуре (дороги, электросети, водоснабжение и т.д.), уменьшении запрещающих и предписывающих законов и легализации неформальной собственности [Turner 1968]. В работах Дж. Тернера, также как и других сторонников либерального подхода, сквоттеры описываются не как пассивные и маргинальные индивиды, а как творческие люди, бросающие вызов жизненным трудностям и самостоятельно решающие жилищную проблему. Важную роль в решении жилищного вопроса Дж. Тернер отводит коллективным практикам самопомощи и самоорганизации внутри сквоттерских поселений, которые способствуют не только строительству жилья, но и формированию местных сообществ [Turner 1996].

В логике либерального подхода к проблеме неформальных поселений работали и П. Ллойд, и С. Лобо, и А. Лидз, и Дж. Перлман и другие. Дж. Перлман в своем исследовании фавел Рио-де-Жанейро пришла к выводу, что маргинальность выступает как мифом, так и описанием социальной реальности. Вопреки популярным взглядам о сквоттерских поселениях как маргинальных очагах социальной дезорганизации и радикальной политики, результаты ее эмпирического исследования показали, что жители фавел были социально хорошо организованы, сплочены, оптимистичны, трудолюбивы в экономической деятельности, а их политические взгляды нельзя назвать ни апатичными, ни радикальными [Perlman 1976, pp. 242-243]. Миф о маргинальности жителей фавел, по мнению Дж. Перлман, создают представители политических и экономических элит, которые заинтересованы в приобретении земли, занятой неформальными поселениями. Такая политика нередко заканчивалась сносом этих районов в рамках 
программы переселения этих сообществ, что приводило к воплощению мифа о маргинальности в социальную реальность [Perlman 1976, p. 195].

В этот период были опубликованы исследования, в которых опровергались точки зрения о политической пассивности или политическом радикализме жителей неформальных поселений. В этих работах сквоттерские поселения рассматривались как интегральная часть политической системы и утверждалось, что сельские мигранты хорошо интегрированы в политические структуры своих стран и часто способны манипулировать этими структурами в собственных интересах [Handelman 1975, p. 48; Peattie, Aldrete-Haas 1981, pp. 163-164]. Дэвид Коллиер на материалах Перу, анализируя политические функции сквоттерских поселений («новых поселений» - pueblos jovenes) для государственного аппарата, показывал, что во многих странах, включая Перу, имеется широкая поддержка со стороны правительств и политических партий нелегальных земельных захватов, с помощью которых создаются подобные поселения [Collier 1976]. В Перу эту политику вовлеченности правительства можно ранжировать от тайного одобрения сквоттерских захватов до открытой публичной поддержки в формировании новых поселений. Эта политика, с точки зрения Д. Коллиера, выступала инструментом в руках элит с целью кооптации низших классов, с одной стороны, для получения политической поддержки в виде избирательных голосов, а с другой, использовалась как стратегия предотвращения радикальных политических изменений в Перу [Collier 1976].

Важно отметить, что сторонники либерального подхода отказались от рассмотрения жителей неформальных поселений как однородной недифференцированной массы сельских мигрантов и/или городских бедняков. Во-первых, сквоттерские поселения на городских окраинах (slums of hope) были отделены от бедных трущоб, расположенных в центре города (slums of despaire). Во-вторых, было показано, что в сквоттерских поселениях проживают жители с разными социально-экономическими и правовыми характеристиками. В то же время главным объектом исследования сторонников либерального подхода стали сквоттеры-землевладельцы, что, по мнению А. Гилберта, определялось идеологическим фактором, так как именно эта социальная группа, с точки зрения либералов, выступала главным агентом решения жилищного вопроса в городах третьего мира. Арендаторы, в свою очередь, ассоциировались с трущобами в центральных частях городов и практически не изучались в этот период [Gilbert 1983, pp. 449-450]. В результате фигура сквоттера-землевладельца стала центральным элементом романтического образа сквоттерских поселений. Разрушая мифы, созданные в рамках теории модернизации, сторонники либерального подхода породили свой собственный миф о героическом сквоттере-землевладельце.

Другую картину сквоттерских поселений попытались показать сторонники марксистского подхода, в первую очередь последователи теории зависимого развития. Марксисты критиковали приверженцев либерального подхода за деполитизацию проблемы неформальных поселений и считали, что первоначальные причины бедности и сквоттинга как воплощения бедности заключаются в структуре капиталистической системы [Hushzermeyer 2004, p. 33]. Р. Берджесс с марксистских позиций подверг критике либеральную концепцию самопомощи Дж. Тернера [Burgess 1977]. Как отмечал Р. Берджесс, для того чтобы понять процесс формирования этих поселений, необходимо учитывать не только интересы 
неформальных владельцев земли и жилья, но также принимать во внимание и потребности арендаторов и законных землевладельцев, политических посредников (которые могут выполнять функцию неформальных агентов недвижимости), профессиональных захватчиков (неформальных застройщиков), строительных рабочих, ростовщиков (неформальных финансистов), предлагающих кредиты для строительства [Burgess 1977, p. 52]. По мнению Р. Берджесса, для работ Дж. Тернера характерна переоценка потребительской стоимости жилья и недооценка рыночной (меновой) стоимости жилья и социально-экономической дифференциации населения в сквоттерских поселениях [Burgess 1977, pp. 51-52]. Р. Берджесс указывал, что значительная часть жилья в сквоттерских поселениях была возведена с использованием оплаченного квалифицированного и неквалифицированного труда [Burgess 1978, p. 1106]. Даже в том случае, если дом был построен для собственного проживания самостоятельно, то это вовсе не означает, что подобное жилье следует рассматривать вне рамок процесса товарного капиталистического производства: во-первых, самостоятельное возведение дома требует покупки строительных материалов на рынке; во-вторых, труд, потраченный при строительстве, имеет ценность на рынке труда; в-третьих, такие дома имеет цену на рынке недвижимости [Burgess 1978, p. 1109]. Важно подчеркнуть, что сторонники марксистского подхода подвергли серьезной критике «романтический» образ самостоятельного сквоттера-землевладельца, созданный либералами, и в тоже время сконструировали собственный «романтический» образ сквоттера как потенциального революционера.

\section{Период концептуального плюрализма (1980-е гг. - настоящее время)}

С 1980-х гг. с расширением географии изучения неформальных поселений количество эмпирических исследований по этой тематике увеличилось, что привело появлению критических оценок некоторых концептов «романтического» периода, в результате чего сложилась ситуация концептуального плюрализма, в период которой ряд ученых отчасти вернулись к идеям модернизационного подхода. Другая группа авторов (в первую очередь неомарксисты) продолжили развивать свои идеи, но при этом они практически отказались от «романтического» образа сквоттера как потенциального революционера; некоторые ученые оставались верными основным положениям либерального «романтического» подхода (например, Э. де Сото и его последователи).

Главный критический аргумент в отношении «романтического» подхода состоял в том, что его сторонники свои оптимистические идеи о позитивной адаптации жителей сквоттерских поселений экстраполировали на все неформальные поселения, опираясь лишь на несколько эмпирических кейсов. При этом новые эмпирические исследования не всегда подтверждали идеи об успешной адаптации сквоттеров. Все больше ученых приходили к выводу, что сквоттерские поселения очень разные, и для их жителей характерны различные адаптивные стратегии: так, М. Кастельс проанализировал роль общественных движений сквоттеров в неформальных поселениях Мехико, Лимы и Сантьяго и показал, что эти движения находятся в зависимости от консервативных правительств, которые оказывают 
патерналистскую поддержку сквоттерам в обмен на избирательные голоса и политическую лояльность [Castells 1983]. По мнению М. Кастельса, главная причина их зависимости - это уязвимость их статуса как городских жителей, поскольку без политической поддержки государства они не имели бы даже прав на физическое присутствие в городе. Как отмечал М. Кастельс, роль сквоттеров в латиноамериканских городах аналогична роли иностранных трудовых мигрантов в развитых капиталистических странах [Castells 1983, p. 211], и именно по этим причинам практически невозможна полноценная интеграция жителей неформальных поселений в социально-экономическую и политическую систему латиноамериканских стран. Также пессимистически он оценивал роль общественных движений сквоттеров, сомневаясь, что они способны стать движущей силой социальной трансформации общества [Castells 1983]. Со своей стороны С. Экштейн подвергла критике классификацию трущоб Ч. Стокса, популярную среди сторонников «романтического» подхода, указав на то, что районы в центральных частях городов не обязательно являются «трущобами безысходности», а сквоттерские поселения не всегда представляют собой успешные примеры «трущоб надежды» [Eckstein 1990].

Второй важный аргумент критики «романтического» подхода состоял в том, что его сторонники хотя и признавали социальную неоднородность населения неформальных поселений, но сосредоточили свое внимание на группе сквоттеров-землевладельцев, практически не замечая другие социальные группы [Davis 2006, p. 42]. При этом новые эмпирические исследования показали, что сквоттинг - далеко не универсальный феномен в городах третьего мира, и существуют другие неформальные стратегии обретения городской земли: незаконный захват земли для строительства жилья не становится характерной особенностью, например, для сельских мигрантов в городах Колумбии [Gilbert, Ward 1985]. Если для городов Латинской Америки характерны массовые организованные захваты земли для строительства неформальных поселений (нередко при поддержке политических деятелей), то в Африке, на Среднем Востоке и в Азии создание неформальных поселений - это, скорее, постепенный процесс, который происходит часто на индивидуальной основе [Potter, Lloyd-Evans 1998, pp. 140-141]. Наряду со стратегией захвата, недвижимость может быть куплена или арендована на неформальном рынке. При этом выбор той или иной стратегии обретения земли и жилья лишь частично определяется личными предпочтениями мигрантов, а, скорее, обуславливаются структурными условиями, которые ограничивают этот выбор [Gilbert, Ward 1985].

В 1980-х гг. ряд исследователей обратили внимание на то, что бесплатный сквоттинг, который идеализировался сторонниками «романтического» подхода, оказался временным феноменом урбанизации третьего мира и уходит в прошлое [Gilbert 1983; Amis 1984; Smart 1986], и все чаще сфера неформального строительства подвергается коммерциализации [Amis 1984; Smart 1986; Balaban 2011; Harris 2014]. Даже там, где сквоттинг сохранился как стратегия обретения городской земли, он редко обходился без издержек: сквоттеры часто вынуждены платить взятки политикам, гангстерам и полиции [Berner 2002, pp. 230-233]. Изучение процессов коммерциализации привело к тому, что исследователи (помимо сквоттеров-землевладельцев) стали обращать внимание на другие социальные группы, проживающие в неформальных поселениях - арендаторов и «владельцев трущоб» (slumlords) [Gilbert, Ward 1982; Gilbert 1983; Amis 1984]. 
В свою очередь, также изменились взгляды и на сквоттеров-землевладельцев. Если раньше сквоттеры ассоциировались с сельскими мигрантами-бедняками, то с 1980-х гг. сквоттеров-землевладельцев перестали рассматривать как гомогенную группу и наряду с классическими сквоттерами, которые используют жилье на захваченной земле для личного использования, стали исследовать сквоттеров, извлекающих из этого прибыль. При этом группа землевладельцев, получающая прибыль, также представлялась неоднородной. Несмотря на то, что общим признаком для всех них являлось получение ренты, причины ее получения существенно различались: для одних категорий землевладельцев эта рента выступала как дополнительный источник выживания, для других категорий как источник капиталистических сверхдоходов [Kumar 1996, p. 238]. Главными получателями сверхдоходов выступали крупные неформальные собственники земли - «владельцы трущоб» [Berner 2002, p. 230; Davis 2006, pp. 82-84]. В peзультате существенно изменились взгляды на функционирование неформальных рынков недвижимости в сквоттерских поселениях. Если в 1970-е гг. на рынок сквоттерской недвижимости смотрели как на институт, который существовал за пределами легального рынка и действовал по своим собственным экономическим законам [Karpat 1976, p. 80], то в 1980-1990-е гг. исследователи пришли к выводу, что невозможно анализировать неформальный жилищный сектор в отрыве от формальных рынков собственности и системы распределения публичного жилья [Smart 1986, p. 43].

Таким образом, можно утверждать, что для сквоттерских поселений характерна социально-экономическая дифференциация, и в них проживают не только бедняки. Сквоттерские поселения нельзя назвать бесконфликтными пространствами, и внутренние отношения характеризуются как доверием, так и эксплуатацией и зависимостью [Berner 1997, р. 181]. Так, например, У. Балабан пишет, что коммодификация в турецких геджеконду привела к значительному антагонизму между старыми мигрантами, которые превратились в мелкую буржуазию, и новыми приезжими, пополнившими ряды рабочего класса [Balaban 2011]. Существенная социально-экономическая дифференциация в неформальных поселениях вовсе не означает, что полностью отсутствуют возможности для социальной мобильности. Жители сквоттерских поселений не являются ни самым беднейшим, ни самым бесправным сегментами городского населения, и в городе имеются возможности для восходящей мобильности: арендаторы могут стать домовладельцами, а сквоттеры - легальными собственниками земли [Berner 1997, p. 181].

Несмотря на потерю монополии, либеральный «романтический» подход продолжает сохранять некоторые позиции в поле исследований неформальных поселений. Наиболее известным сторонником этого подхода в 1990-2000-е гг. стал перуанский экономист Э. де Сото [De Soto 1989]. При этом важно отметить, что в отличие от идей сторонников либеральной версии «романтического» подхода 1960-1970-х гг. У. Мэнжина и Дж. Тернера, Э. де Сото рассматривает бедняков, проживающих в сквоттерских поселениях, как владельцев неформальной собственности, которая имеет рыночную стоимость. В работах Э. де Сото бедняки (в том числе и жители неформальных поселений) предстают не просто как люди, решающие самостоятельно жилищный вопрос, но и как «героические предприниматели», создающие рыночную экономику в своих странах вопреки политике господствующих элит. 


\section{Исследования неформальных поселений в постсоветских городах}

Сквоттерские поселения широко распространены в городах республик бывшего СССР, в том числе и в российских. Проблема самовольных поселений часто освещается в российских федеральных и региональных СМИ, особенно в случае земельных конфликтов: так, в 2010 г. возник конфликт из-за сноса дачного поселка «Речник» в Москве, который власти рассматривали как незаконный самострой [Федоров 2010]. В 2016 г. в СМИ широко освещался конфликт вокруг сноса цыганской «нахаловки» в поселке Плеханово под Тулой [Гнединская 2016]. Достаточно актуальной проблемой до недавнего времени оставалась и проблема крымско-татарских земельных самозахватов в городах Крыма [Емельянов 2015]. В Москве и на юге европейской России уникальным представляется самозахват земли под гаражи, которые используются в качестве жилья [Селеев, Павлов 2016], а на востоке России наиболее известен случай борьбы городских властей УланУдэ с жителями «нахаловок» [Карбаинов 2007; Бреславский 2014]. Несмотря на распространенность феномена, исследования постсоветских «нахаловок» в основном проводятся в городах азиатской части бывшего СССР (Бишкек, Баку, Алматы, Улан-Удэ), и до сих пор практически отсутствует изучение неформальных поселений в городах европейской части ${ }^{3}$.

Важно отметить, что «нахаловки» не представляют собой явление исключительно постсоветского времени, они существовали и в дореволюционную эпоху, и в советский период. Так, например, данный феномен описывается в дореволюционном Красноярске и послереволюционных Свердловске, Новосибирске, Минске, Улан-Удэ, Баку и др. [Zhimbiev 2000; Румянщев 2008; Гилько 2011; Бон 2013; Лосевская 2014; Бурцев 2014]. В советский период «нахаловки» возникали во многом под влиянием индустриализации 1930-х гг., когда в условиях дефицита жилья городские власти были вынуждены закрывать глаза на незаконное строительство [Zhimbiev 2000, pp. 59-60; Бон 2013]. В 1950-1980-е гг. многие города СССР охватил бум строительства массового общедоступного жилья, что позволило в некоторой степени решить жилищный вопрос, и часть обитателей «самостроев» перебрались в благоустроенные дома. Несмотря на эти изменения, самовольный захват земли для строительства «нахаловок», пусть и в меньших масштабах, продолжался и в этот период [Zhimbiev 2000; Бон 2013]. В конце 1980-х - начале 1990-х гг. в условиях социально-экономического кризиса в ряде городов Советского Союза возникла новая волна строительства самовольного жилья [Kostyukova 1994; Alymbaeva 2013; Румянцев 2008; Кожахметов, Асанбаев 2010; Fryer, Nasritdinov, Satybaldieva 2014]. На появление и воспроизводство самовольных поселений в советское время повлияли три взаимосвязанные причины: во-первых, они были продуктом ускоренной индустриализации, сопутствующей ей урбанизации и миграции населения (в первую очередь сельско-городской), что привело к дефициту жилья в городах, поэтому неслучайно население советских «нахаловок» состояло в основном из рабочих заводов и фабрик; во-вторых, местные власти были заинтересованы в смягчении жилищного вопроса, а руководство промышленных предприятий - в закреплении рабочей силы, и поэтому закрывали глаза на формирование «нахаловок»;

\footnotetext{
3 За исключением Крыма и исследований гаражной экономики на юге России.
} 
в-третьих, в условиях режима государственной собственности практики захвата небольшого участка для строительства жилья на «ничейной» или «общенародной» земле хоть и нарушали советские законы, но были вполне легитимны в рамках советской идеологии собственности [Marcuse 1994; Tsenkova, Potsiou, Badyina 2009].

С распадом СССР формирование сквоттерских поселений в ряде постсоветских городов продолжилось, но отчасти изменились причины их образования. Кардинальная трансформация социально-экономической системы в условиях кризиса 1990-х гг. в странах бывшего СССР привела к сворачиванию социального государства, приватизации государственных функций и переводу различных отраслей на коммерческие рельсы [Tsenkova, Potsiou, Badyina 2009]: в частности, в городах существенно сократились масштабы строительства социального жилья, а оно само превратилось в объект купли-продажи, не всегда доступный для многих слоев населения. Кризис 1990-х гг. особенно сильно ударил по сельскому хозяйству, что послужило причиной роста безработицы и разрушения социальной инфраструктуры в сельской местности. Именно эти социально-экономические процессы содействовали миграции сельских жителей в города. Дороговизна покупки жилья и высокая плата за аренду способствовали тому, что часть сельских мигрантов стали самостоятельно решать жилищный вопрос с помощью захвата земли, приведшему к появлению в ряде постсоветских городов новых сквоттерских поселений [Карбаинов 2007; Alymbaeva 2013; Кожахметов, Асанбаев 2010; Yessenova 2010; Алексеева 2010; Isabaeva 2014; Бреславский 2014]4.

Помимо экономических причин важную роль в формировании постсоветских сквоттерских поселений сыграли также и политические причины. Во-первых, с распадом СССР прекратилась политика удержания населения в сельской местности, в том числе с помощью института прописки [Alymbaeva 2013]. Во-вторых, самовольный захват земли в некоторых случаях поощрялся политиками, одни из которых пытались удержать и легитимировать свою власть, другие, наоборот, использовали ситуацию с самозахватом городской земли как способ достижения власти в стране или регионе. Ярким примером влияния политического контекста стали «новостройки» в Бишкеке [Zhumakadyr kyzy 2012, p. 7; Kostyukova 1994]. Значительную роль политический фактор играл и в случае крымско-татарских земельных самозахватов на окраинах городов Крыма в 1990-2010-е гг. [Uehling 2004; Богомолов, Данилов, Семиволос 2012].

Существенным отличием постсоветских сквоттерских поселений от советских «нахаловок» представляется тот факт, что неформальные поселения начала 1990-х гг. формировались в совершенно ином правовом контексте, в первую очередь связанном с изменением института прав собственности на землю. В республиках бывшего СССР произошла трансформация режима государственной собственности в формат частной собственности, в рамках которого недвижимость превратилась в объект рыночной купли-продажи. Как уже указывалось выше, если в советское время самовольный захват земли для строительства дома рассматривался как легитимный способ реализации права на жилье, то в постсоветскую эпоху данная практика не только нарушала законы, но и теряла

4 Исключением из этого ряда являются неформальные поселения в пригородах городов Крыма, занятых крымскими татарами, многие из которых до репатриации проживали в городах Средней Азии [Uehling 2004, pp. 44-45; Швец 2008, с. 75]. 
легитимность в первую очередь с точки зрения политических и экономических элит, представители которых стали извлекать собственную прибыль из сделок с городской землей, а жители неформальных поселений нередко угрожали их интересам, что привело к активной борьбе чиновников с «самоволками» [Карбаинов 2010; Yessenova 2010].

Другим принципиальным отличием постсоветских «самоволок» от советских «нахаловок» стало изменение их социального и этнического состава: если в «нахаловках» в основном проживали рабочие фабрик и заводов и населялись преимущественно представителями русского этноса [Арутюнян, Дробижева, Сусоколов 1999, c. 79], то в «самоволках» наблюдался достаточно пестрый социальный состав и в некоторых из них селились в первую очередь представители титульных этносов: например, практически 100\% жителей «новостроек» Бишкека заселены сельскими киргизами [Alymbaeva 2013], в сквоттерских поселениях Улан-Удэ, возникших в 1990-2000-е гг., в основном проживают сельские буряты [Карбаинов 2007], а население неформальных поселений в городах Казахстана по большей части состоит из казахов, прибывших из сельской местности [Кожахметов, Асанбаев 2010].

Авторы имеющихся научных публикаций по проблеме постсоветских «самоволок» свои выводы, как правило, строят, опираясь на один из двух методических подходов - «аутсайдерский» или «инсайдерский». «Аутсайдерский» подход выстраивается на основе анализа источников местных СМИ и/или результатов опроса экспертов (чиновников, общественных активистов, местных ученых) и коренных горожан. «Инсайдерский» подход в свою очередь основан на анализе эмпирических данных полевых исследований, проведенных непосредственно в неформальных поселениях. Выбор одного из двух подходов сильно влияет на аргументы, выводы и оценку авторов в отношении постсоветских «самоволок». В то же время имеются публикации, авторы которых пытаются учитывать обе точки зрения.

Одним из важных остается вопрос о том, каким образом сельские мигранты приобретают недвижимость в неформальных поселениях. По мнению «аутсайдеров» (журналистов, чиновников, коренных горожан), сельские мигранты, как правило, получают землю в «нахаловках» путем самозахвата. Эта точка зрения также приводится в ряде научных публикаций [Manzanova 2007; Xaмфрu 2010]: так, описывая «нахаловки» Улан-Удэ, К. Хамфри пишет: «<..> как мигранты приобретают землю? Просто забирают себе» [Хамфри 2010, с. 318]. При этом авторы, опираясь на результаты полевых исследований, показывают более сложную картину. Помимо самозахвата земли имеют место и аренда, и покупка недвижимости в неформальных поселениях [Давыдов, Карбаинов, Симонова, Целищева 2006; Михалев 2008, с. 144-145; Карбаинов 2010; Богомолов, Данилов, Семиволос 2012; Sanghera, Satybaldieva, Rodionov, Serikzhanov, Choibekov, Sultanmuratova 2012, p. 17; Fryer, Nasritdinov, Satybaldieva 2014, pp. 183-184]. Значительную роль на рынке купли-продажи и аренды недвижимости в постсоветских сквоттерских поселениях играют неформальные землевладельцы, которые захватывают или скупают крупные участки земли, делая это нередко при поддержке чиновников, потом они сдают ее в аренду или продают мигрантам ${ }^{5}$.

\footnotetext{
5 Существование рынков недвижимости в неформальных поселениях описываются исследователями в Симферополе, Улан-Удэ и Бишкеке [Богомолов, Данилов, Семиволос 2012; Isabaeva 2013, p. 145; Isabaeva 2014, p. 253; Fryer, Nasritdinov, Satybaldieva 2014, pp. 183-184; Карбаинов 2014, с. 97].
} 
Другой актуальной темой, на которую обращают внимание ученые, представляется проблема взаимоотношений жителей неформальных поселений с коренными горожанами. В публичном дискурсе последних нередко культивируется образ сельских мигрантов как чужаков, которые вторгаются в город, разрушают городскую культуру и привычный образ жизни [Давыдов, Карбаинов, Симонова, Целищева 2006, с. 141-142; Космарская 2011]. Здесь стоит отметить, что сельский чужак - это, как правило, представитель титульного этноса, при этом в производстве негативных представлений о чужаках участвуют и представители титульных этносов, проживающих в городах, противопоставляющие себя сельчанам [Карбаинов 2004; Румянщев 2008; Космарская 2011]. Коренные горожане используют в отношении сельских мигрантов различные презрительные выражения: головары, мырки, мамбеты, чушки [Карбаинов 2004; Румяниев 2008; Космарская 2011]. С точки зрения коренных горожан, главными местами проживания сельских чужаков в городе становятся самовольные поселения - очаги бескультурья, грубости и преступности [Карбаинов 2007]. Этот негативный образ также воспроизводится и в академическом дискурсе через призму идей о рурализации постсоветских городов и маргинальности сельских мигрантов [Батомункуев 2005; Manzanova 2007; Добрецова 2006], которые при этом рассматриваются как «однородная масса с отсутствием ярко выраженного социального деления» [Кожахметов, Асанбаев 2010, с. 64]. Другие авторы критически настроены по отношению к сторонникам данных взглядов: Н.П. Космарская на примере Бишкека в качестве альтернативы идеям концепции рурализации предлагает анализировать процессы сельско-городской миграции в постсоветских городах с помощью идеи демодернизации [Космарская 2011, с. 611-612]. По ее мнению, во многом антимигрантский дискурс у коренных горожан Бишкека - это следствие ностальгии по советскому наднациональному индустриально-урбанистическому порядку, выступает символическим противодействием демодернизации [Космарская 2011, с. 611-612]. В другом исследовании, посвященном «нахаловкам» Улан-Удэ, было показано, что конструирование и воспроизводство образа сельского чужака (головара) хоть и остается для горожан важным условием поддержания городской идентичности, но при этом дискурсивная граница между «городскими» и «сельскими» достаточно размыта и подвижна. Многие горожане оказываются сами недавними выходцами из сельской местности или мигрантами во втором-третьем поколении, которые поддерживают тесные связи с деревенскими родственниками [Давыдов, Карбаинов, Симонова, Целищева 2006, с. 142]. Также в данном исследовании на основе полевых данных было представлено, что многие страхи в отношении населения «нахаловок» преувеличены, и сельские мигранты, проживающие в неформальных поселениях Улан-Удэ, в социальном и экономическом разрезе не представляют собой однородную группу [Давыљов, Карбаинов, Симонова, Целищева 2006]

Еще одной существенной темой в исследованиях постсоветских сквоттерских поселений является вопрос о стратегиях социально-экономической адаптации сельских мигрантов в городе. Одни авторы исходят из того, что жители «самоволок» - это в основном представители бедных слоев, как правило, с низким уровнем образования, у которых не хватило денег для покупки законной городской недви-

6 К подобным выводам пришли и другие авторы, которые опирались на результаты полевых исследований в неформальных поселениях [Nasritdinov, Zhumakadyr kyzy, Asanalieva 2015]. 
жимости [Содномпилова 2009, с. 174-175; Sanghera, Satybaldieva 2012, pp. 103-104; Sanghera, Satybaldieva, Rodionov, Serikzhanov, Choibekov, Sultanmuratova 2012]. Coответственно, по их мнению, адаптация жителей неформальных поселений происходит в рамках экономики выживания или «моральной экономики» [Sanghera, Satybaldieva 2012]. Необходимость физического выживания приводит к тому, что многие мигранты вынуждены работать в сфере неформальной (или даже нелегальной) экономики, как правило, выполняя низкооплачиваемую работу, связанную с неквалифицированным физическим трудом [Kostyukova 1994; Manzanova 2007; Alymbaeva 2013; Содномпилова 2009; Sanghera, Satybaldieva 2012]. В ходе адаптации сельские мигранты сталкиваются с множеством административных барьеров, в первую очередь с отсутствием регистрации в городе, что создает существенные сложности в поиске жилья, получении работы и в доступе к общественным благам (образованию, медицине) [Sanghera, Satybaldieva, Rodionov, Serikzhanov, Choibekov, Sultanmuratova 2012]. Таким образом, создается образ жителей неформальных поселений как социально исключенной группы бедняков и маргиналов [Sanghera, Satybaldieva, Rodionov, Serikzhanov, Choibekov, Sultanmuratova 2012; Isabaeva 2014].

Другие исследователи оспаривают эту точку зрения, утверждая, что жители постсоветских неформальных поселений - это не однородная группа в социально-экономическом плане, и поэтому далеко не все заняты в сфере неформальной экономики. Например, по мнению Э. Насритдинова и его соавторов, представления о всеобщей бедности и маргинальности жителей «новостроек» Бишкека преувеличены. Наряду с «новостройками», населенными бедными мигрантами, также есть «новостройки», население которых скорее можно отнести к среднему классу: результаты опроса, проведенного в «новостройках», показывают, что $32 \%$ респондентов имеют высшее образование [Nasritdinov, Zhumakadyr kyzy, Asanalieva 2015; Fryer, Nasritdinov, Satybaldieva 2014, p. 197]. В «нахаловках» Улан-Удэ проживает немало представителей бывшей сельской интеллигенции с высшим образованием, занятых в бюджетной сфере экономики [Давыљов, Карбаинов, Симонова, Целищева 2006, с. 148-149]. В то же время для некоторых жителей «самоволок» работа в неформальном секторе становится не просто стратегией выживания в рамках «моральной экономики», а, скорее, бизнес-стратегией, направленной на получение прибыли: в первую очередь речь идет о неформальных землевладельцах, которые продают и сдают в аренду недвижимость в самовольных поселениях, например, топбашы или «земельная мафия» в Бишкеке [Nasritdinov, Zhumakadyr kyzy, Asanalieva 2015; Fryer, Nasritdinov, Satybaldieva 2014; Isabaeva 2014], «неформальные капиталисты» в Улан-Удэ [Карбаинов 2014, с. 97].

Следует подчеркнуть, что большую роль в социально-экономической адаптации жителей самовольных поселений в городе играют родственно-земляческие сети, которые смягчают многие проблемы адаптации, например, получение городской прописки или поиск работы [Давыдов, Карбаинов, Симонова, Целищева 2006, с. 151-152; Manzanova 2007; Румяниев 2008, с. 239-242; Содномпилова 2009, с. 174; Кожахметов, Асанбаев 2010, с. 8; Хамфри 2010, с. 218; Fryer, Nasritdinov, Satybaldieva 2014, p. 189]. При этом родственно-земляческие связи существуют не только в самих неформальных поселениях, что приводит к формированию земляческих кварталов [Давыдов, Карбаинов, Симонова, Целищева 2006, с. 152; Румянщев 2008], в них также включены родственники и земляки, проживающие за пределами «самоволок», в том числе и коренные горожане [Давылдов, Карбаинов, Симонова, Целищева 2006, с. 152]. 
Еще одним вопросом, вызывающим интерес ученых, выступает проблема отношений жителей неформальных поселений с государственными институтами и другими политическими акторами. Эти отношения достаточно противоречивы: с одной стороны, для государства сельские мигранты, проживающие в «самоволках», являются нарушителями закона, с которыми необходимо бороться [Давыдов, Карбаинов, Симонова, Целищева 2006; Yessenova 2010], с другой, некоторые политические деятели заинтересованы в поддержке жителей сквоттерских поселений и пытаются их использовать для достижения своих целей [Kostyukova 1994]. Власти постсоветских городов прибегают к различным стратегиям решения проблемы сквоттерских поселений: игнорированию, насильственному сносу и выселению их жителей, расселению или легализации [Yessenova 2010; Zhumakadyr $k y z y$ 2012]. Нейтральная политика государственных институтов в отношении неформальных поселений нередко сменяется на негативную под влиянием интереса коммерческих структур к пригородной земле, которую занимают «самоволки» [Yessenova 2010; Кожахметов, Асанбаев 2010, с. 42-46]: так, неслучайно активная борьба с «нахаловками» Улан-Удэ развернулась после принятия в 2001 г. Земельного кодекса РФ, который узаконил куплю-продажу земли [Карбаинов 2010]. Попытки сноса самовольных поселений чаще всего приводят к серьезным конфликтам, в ходе которых жители «самоволок» мобилизуются и организуют различные протестные акции (митинги, перекрытия транспортных магистралей и т.д.) [Давblдов, Карбаинов, Симонова, Целищева 2006; Yessenova 2010; Sanghera, Satybaldieva, Rodionov, Serikzhanov, Choibekov, Sultanmuratova 2012]. Значимую роль в политической мобилизации играют институты самоорганизации, существующие либо в форме НКО, либо неформально в виде команды активистов, выбранных жителями «самоволок». Помимо политической деятельности, эти институты также решают проблемы сквоттерских поселений, связанные с развитием социальной инфраструктуры (электроснабжение, водоснабжение и т.д.) [Давылов, Карбаинов, Симонова, Целищева 2006, с. 149-151; Fryer, Nasritdinov, Satybaldieva 2014, p. 188]. Исследователи также уделяют внимание стратегиям обоснования прав собственности на землю и морального оправдания, к которым прибегают жители постсоветских сквоттерских поселений [Sanghera, Satybaldieva 2012; Карбаинов 2010 ].

\section{Заключение}

Таким образом, по результатам анализа литературы можно выделить три этапа в изучении сквоттерских поселений сельских мигрантов в развивающихся странах. На первом этапе (1950 - первая половина 1960-х гг.) под влиянием теорий модернизации сложились три основные точки зрения: (1) сквоттерские поселения как «транзитные зоны»; (2) неформальные поселения как рассадники социальных болезней и преступности, социальной и личностной дезорганизации; (3) неформальные поселения как «сельские анклавы» в городе. На данном этапе феномен сквоттерских поселений рассматривался как серьезная проблема для городского развития. На втором этапе (вторая половина 1960-х - 1970-е гг.) исследователи попытались развеять прежние мифы о сквоттерских поселениях. Для этого этапа характерна конкуренция сторонников либерального и марксистского 
подходов. Сторонники либерального подхода показали, что неформальные поселения не являются проблемой, а, скорее, выступают инструментом решения жилищного кризиса в городах третьего мира, и создали романтический образ сквоттера - землевладельца. Сторонники марксистского подхода в свою очередь рассматривали сквоттеров как потенциальных революционеров. На третьем этапе (1980-е гг. - настоящее время) произошел пересмотр многих романтических представлений о сквоттерских поселениях предыдущего этапа. В этот период в исследованиях неформальных поселений сложилась ситуация концептуального плюрализма.

Несмотря на то, что сквоттерские поселения в постсоветских городах стали объектом исследования начиная только с 1990-х гг., по своим используемым концепциям, результатам и выводам они вполне сопоставимы с исследованиями, проводимыми в развивающихся странах. Можно выделить следующие ключевые темы в исследованиях постсоветских неформальных поселений:

- стратегии обретения недвижимости в самовольных поселениях;

- проблема взаимоотношений жителей неформальных поселений с коренными горожанами;

- стратегии социально-экономической адаптации сельских мигрантов, проживающих в сквоттерских поселениях;

- отношения жителей неформальных поселений с государственными институтами и другими политическими акторами.

Надеемся, что в будущем география изучения неформальных поселений в постсоветских городах существенно расширится и появится больше возможностей для проведения сравнительных исследований этого интересного феномена.

\section{Литература}

Алексеева М.С. (2010) Сельско-городская миграция и проблема самовольных поселений в постсоветской Бурятии: социально-экологический подход // Журнал социологии и социальной антропологии. Т. ХІІІ. № 4. С. 128-129.

Арутюнян Ю.В., Дробижева Л.М., Сусоколов А.А. (1999) Этносоциология. М.: Аспект Пресс. Батомункуев С.Д. (2005) Этническая идентичность в условиях постсоветского Улан-Удэ // Байкал. Спецвыпуск. С. 146-151.

Богомолов А.В., Данилов С.И., Семиволос И.Н. (2012) Земельные споры как фактор социальных конфликтов в Крыму // Східний світ. № 4. С. 164-188.

Бон Т.М. (2013) «Минский феномен». Городское планирование и урбанизация в Советском Союзе после Второй мировой войны. М.: РОССПЭН.

Бреславский А.С. (2014) Незапланированные пригороды: сельско-городская миграция и рост Улан-Удэ в постсоветский период. Улан-Удэ: Изд-во БНЦ СО РАН.

Бурцев А.Г. (2014) Самодеятельное строительство жилья в Свердловске 1924-1925 гг. Кооперация и частники // Архитектон: известия вузов. № 48 // http://archvuz.ru/2014_4/10

Гилько М.А. (2011) Транссибирская магистраль и проблемы городского хозяйства дореволюционного Красноярска // Вестник КрасГАУ. № 12. С. 256-263.

Гнединская А. (2016) Снос домов в Плеханово цыгане назвали «страшным днем табора» // Московский комсомолец // http://www.mk.ru/social/2016/05/30/snos-domov-vplekhanovo-cygane-nazvali-strashnym-dnem-tabora.html

Давыдов В.Н., Карбаинов Н.И., Симонова В.В., Целищева В.Г. (2006) Агинская street, танец с огнем и алюминиевые стрелы: Присвоение культурных ландшафтов. Хаба- 
ровск: Хабаровский научный центр ДВО РАН, Хабаровский краевой краеведческий музей им. Н.И. Гродекова.

Добрецова Н.Н. (2006) Рурализация и поглощение городской субкультуры // ЭКО. № 9. С. $116-130$.

Емельянов Д.Н. (2015) Земельные отношения в современном Крыму // Вестник Рязанского государственного агротехнического университета. № 1 (25). С. 85-89.

Карбаинов Н. (2004) «Городские» и «головары» в Улан-Удэ (молодежные субкультуры в борьбе за социальное пространство города) // Вестник Евразии. № 2. С. 170-183.

Карбаинов Н.И. (2007) «Нахаловки» Улан-Удэ: «огораживание» пригородной земли // Социологические исследования. № 11. С. 136-139.

Карбаинов Н.И. (2010) Стратегии обоснования прав собственности на землю в ситуации правового плюрализма (на примере земельных споров в городе Улан-Удэ) // Журнал социологии и социальной антропологии. Т. ХІІІ. № 4. С. 140-157.

Карбаинов Н.И. (2014) Как владельцы (не) становятся частными собственниками (на примере земельных конфликтов в Улан-Удэ и Сочи) // Журнал социологии и социальной антропологии. T. XVII. № 5 (76). С. 85-108.

Кожахметов А., Асанбаев М. (2010) Внутренняя миграция в Казахстане: в поисках решения. Алматы: РОО «Шанырак», Центр социально-гуманитарных исследований «Аспект М».

Космарская Н.П. (2011) «Понаехали тут...» по-бишкекски: Мигранты и старожилы в городе как зеркало «киргизской революции» // Гучинова Э.-Б., Комарова Г. (ред.) Антропология социальных изменений. Исследования по социально-культурной антропологии: Сборник статей. М.: РОССПЭН. С. 595-614.

Лосевская О.Д. (2014) История появления «депрессивных» пространств в центральной части г. Новосибирска // Баландинские чтения. Т. 9. № 2. С. 231-237.

Михалев А.В. (2008) Конструирование традиционности в пространстве самостроя современного Улан-Удэ: этнографический очерк // Известия Алтайского государственного университета. № 4-5. С. 142-145.

Румянцев С. (2008) Нефть и овцы: Из истории трансформаций города Баку из столицы в столицу // Милерюс Н., Коуп Б. (ред.) Р.S. Ландшафты: оптики городских исследований. Сборник научных трудов. Вильнюс: ЕГУ. С. 228-266.

Селеев С.С., Павлов А.Б. (2016) Гаражники. М.: Страна Оз.

Содномпилова M.M. (2009) Сельско-городская миграция в Бурятии: формирование транслокального сообщества // Скрынникова Т.Д. (ред.) Город и село в постсоветской Бурятии: социально-антропологические очерки. Улан-Удэ: Издательство БНЦ СО РАН. C. $165-186$.

Федоров А. (2010) «Речник» - это «нахаловка» // Московский комсомолец // http://www.mk.ru/social/article/2010/06/20/510996-rechnik-eto-nahalovka.html

Хамфри К. (2010) Постсоветские трансформации в азиатской части России (антропологические очерки). М.: Наталис.

Швец А.Б. (2008) Паспортизация социокультурных противоречий в Крыму // Геополитика и экогеодинамика регионов. Т. 4. № 1-2. С. 72-79.

Alymbaeva A. (2013) Internal Migration in Kyrgyzstan: A Geographical and Sociological Study of Rural Migration // Migration and Social Upheaval as the Face of Globalization in Central Asia (ed. Laruelle M.), Boston: Brill, pp. 117-148.

Amis P. (1984) Squatters or Tenants: the Commercialization of Unauthorized Housing in Nairobi // World Development, vol. 12, no 1, pp. 87-96.

Balaban U. (2011) The Enclosure of Urban Space and Consolidation of the Capitalist Land Regime in Turkish Cities // Urban Studies, vol. 48, no 10, pp. 2162-2179.

Berner E. (1997) Defending a Place in the City: Localities and the Struggle for Urban Land in Metro Manila, Quezon City: Ateneo de Manila University Press.

Berner E. (2002) Learning from Informal Markets: Innovative Approaches to Land and Housing Provision // Development and Cities: Essays from Development in Practice (eds. Westendorff D., Eade D.), Oxford, pp. 226-247.

Burgess R. (1977) Self-help Housing: A New Imperialist Strategy? A Critique of the Turner School // Antipode, vol. 9, no 2, pp. 50-59. 
Burgess R. (1978) Petty Commodity Housing or Dweller Control? A Critique of John Turner's Views on Housing Policy // World Development, vol. 6, no 9, pp. 1105-1133.

Castells M. (1983) The City and the Grassroots: a Cross-Cultural Theory of Urban Social Movements, University of California Press.

Collier D. (1976) Squatters and Oligarchs: Authoritarian Rule and Policy Change in Peru, Baltimore: The Johns Hopkins University Press.

Cornelius W.A. (1977) The Political Sociology of Cityward Migration in Latin America: Toward Empirical Theory // Third World Urbanization (eds. Abu-Lughod J., Hay JR.R), New York, London, Toronto: Methuen, pp. 213-224.

Costello M.A. (1987) Slums and Squatter Areas as Entrepots for Rural-Urban Migrants in a Less Developed Society // Social Forces, vol. 66, no 2, pp. 427-445.

Davis M. (2006) Planet of Slums, London \& New York: Verso.

De Soto H. (1989) The Other Path: The Invisible Revolution in the Third World, New York: Basic Books

Demirtaş N. (2009) Social Spatialization in a Turkish Squatter Settlements: Dualism Strategy and Tactic Reconsidered, Frankfurt am Main: Peter Lang GmbH.

Eckstein S. (1990) Urbanization Revisited: Inner-city Slum of Hope and Squatter Settlement of Despair // World Development, vol. 18, no 2, pp. 165-181.

Erman T. (2001) The Politics of Squatter (gecekondu) Studies in Turkey: the Changing Representations of Rural Migrants in the Academic Discourse // Urban Studies, vol. 38, no 7, pp. 983-1002.

Fryer P., Nasritdinov E., Satybaldieva E. (2014) Moving Toward the Brink? Migration in the Kyrgyz Republic // Central Asian Affairs, vol. 1, no 2, pp. 171-198.

Gilbert A. (1983) The Tenants of Self-Help Housing: Choice and Constraint in the Housing Markets of Less Developed Countries // Development and Change, vol. 14, no 3, pp. 449-477.

Gilbert A.G., Ward P.M. (1982) Residential Movement Among the Poor: the Constraints on Housing Choice in Latin American Cities // Transactions of the Institute of British Geographers, vol. 7, no 2, pp. 129-149.

Gilbert A., Ward P.M. (1985) Housing, the State, and the Poor: Policy and Practice in Three Latin American Cities, Cambridge University Press.

Handelman H. (1975) The Political Mobilization of Urban Squatter Settlements. Santiago's Recent Experience and Its Implications for Urban Research // Latin American Research Review, vol. 10, no 2, pp. 35-72.

Harris R. (2014) Urban Land Markets: a Southern Exposure // The Routledge Handbook on Cities of the Global South (eds. Parnell S., Oldfield S.), New York: Routledge.

Hushzermeyer M. (2004) Unlawful Occupation: Informal Settlements and Urban Policy in South Africa and Brazil, Trenton, NJ: Africa World Press.

Isabaeva E. (2014) From Denizens to Citizens in Bishkek: Informal Squatter-Settlement Residents in Urban Kyrgyzstan // The Journal of Social Policy Studies, no 2, pp. 249-260.

Karpat K.H. (1976) The Gecekondu: Rural Migration and Urbanization, Cambridge: Cambridge University Press.

Kostyukova I. (1994) The Towns of Kyrgyzstan Change Their Faces: Rural-urban Migrants in Bishkek // Central Asian Survey, vol. 13, no 3, pp. 425-434.

Kumar S. (1996) Subsistence and Petty Capitalist Landlords: a Theoretical Framework for the Analysis of Landlordism in Third World Urban Low Income Settlements // International Journal of Urban and Regional Research, vol. 20, no 2, pp. 317-329.

Lloyd P. (1979) Slums of Hope?: Shanty Town of the Third World, Manchester: Manchester University Press.

Lomnitz L.A. (1977) Networks and Marginality: Life in a Mexican Shantytown, New York: Academic Press.

Mangin W. (1967) Latin American Squatter Settlements: A Problem and a Solution // Latin American Research Review, vol. 2, no 3, pp. 65-98.

Manzanova G. (2007) City of Migrants: Contemporary Ulan-Ude in the Context of Russian Migration // Urban Life in Post-Soviet Asia (eds. Alexander C., Buchli V., Humphrey C.), University College London Press, pp. 125-135. 
Marcuse P. (1996) Privatization and its Discontents: Property Rights in Land and Housing in the Transition in Eastern Europe // Cities after Socialism: Urban and Regional Change and Conflict in Post-Socialist Societies (eds. Andrusz G., Harloe M., Szelenyi I.), Oxford: Blackwell Publisher, pp. 119-191.

Nasritdinov E., Zhumakadyr kyzy B., Asanalieva D. (2015) Myths and Realities of Bishkek's Novostroikas // Kyrgyzstan beyond 'Democracy Island' and 'Failing State': Factoring Social and Political Challenges in a Post-Soviet Society (eds. Laruelle M., Engvall J.), Lanham: Lexington Books, pp. 145-163.

Peattie L., Aldrete-Haas J.A. (1981) "Marginal” Settlements in Developing Countries: Research, Advocacy of Policy, and Evolution of Programs // Annual Review of Sociology, vol. 7, pp. $157-175$.

Perlman J. (1976) The Myth of Marginality: Urban Poverty and Politics in Rio de Janeiro, Berkeley: University of California Press.

Potter R., Lloyd-Evans S. (1998) The City in the Developing World, Singapore: Longman.

Sanghera B., Satybaldieva E. (2012) Ethics of Property, Illegal Settlements and the Right to Subsistence // International Journal of Sociology and Social Policy, vol. 32, no 1-2, pp. 96-114.

Sanghera B., Satybaldieva E., Rodionov A., Serikzhanova S., Choibekov N., Sultanmuratova K. (2012) Illegal Settlements and City Registration in Kyrgyzstan and Kazakhstan: Implications for Legal Empowerment, Politics and Ethnic Tensions. Central Eurasia Project, New York: Open Society Foundations.

Smart A. (1986) Invisible Real Estate: Investigations into the Squatter Property Market// International Journal of Urban and Regional Research, vol. 10, no 1, pp. 29-45.

Snyder P. (1976) Neighborhood Gatekeepers in the Process of Urban Adaptation: Cross-ethnic Commonalities // Urban Anthropology, vol. 5, no 1, pp. 35-52.

Stokes Ch. (1962) A Theory of Slums // Land Economics, vol. 38, no 3, pp. 187-197.

Tsenkova S. (2012) Urban Planning and Informal Cities in Southeast Europe // Journal of Architectural and Planning Research, vol. 29, no 4, pp. 292-305.

Tsenkova S., Potsiou C., Badyina A. (2009) Self-made Cities: In Search of Sustainable Solutions for Informal Settlements in the United Nations Economic Commission for Europe Region, New York and Geneva: United Nations Publications.

Turner J. (1968) Uncontrolled Urban Settlement: Problems and Policies // International Social Development Review, no 1, pp. 107-128.

Turner J. (1996) From Housing to Building Community // City: Analysis of Urban Trends, Culture, Theory, Policy, Action, vol. 1, no 3-4, pp. 30-39.

Uehling G.L. (2004) Beyond Memory: The Crimean Tatars' Deportation and Return, New York: Palgrave Macmillan.

Yessenova S. (2010) Borrowed Places: Eviction Wars and Property Rights Formalization in Kazakhstan // Economic Action in Theory and Practice: Anthropological Investigations (ed. Wood D.C.), Bingley: Emerald, pp. 11-46.

Zhimbiev B. (2000) History of the Urbanization of a Siberian City: Ulan-Ude, London: The White Horse Press.

Zhumakadyr kyzy B. (2012) Development in Urbanized Settings: A Study of Novostroikas in Bishkek. Unpublished Bachelor's thesis, American University of Central Asia, Bishkek. 


\title{
Favelas, Gecekondu, Nakhalovki: Squatter Settlements in the Cities of Developing and Post-Soviet Countries
}

\author{
N. KARBAINOV*
}

\begin{abstract}
*Nikolay Karbainov - Research Fellow, Sociological Institute of the Federal Center of Theoretical and Applied Sociology of the Russian Academy of Sciences. Address: 25/14, $7^{\text {th }}$ Krasnoarmeyskaya St., Saint Petersburg, 190005, Russian Federation. E-mail: nkarbainov@gmail.com
\end{abstract}

Citation: Karbainov N. (2018) Favelas, Gecekondu, Nakhalovki: Squatter Settlements in the Cities of Developing and Post-Soviet Countries. Mir Rossii, vol. 27, no 1, pp. 135-158 (in Russian). DOI: 10.17323/1811-038X-2018-27-1-135-158

\begin{abstract}
This article considers the key concepts and topics of research on squatter or informal settlements in developing countries, including post-Soviet ones. During the first period (1950-early 1960s) three main viewpoints dominated in the field of such research: 1) squatter settlements as "transition zones"; 2) informal settlements as nests for crime, social disorder, social and personal disorganization; 3) informal settlements as "rural enclaves" in a city. The phenomenon of squatter settlements was considered a serious social problem for urban development. During the second period (late 1960s-1970s) researchers tried to dissolve the "myths" formed during the first period. The contestation between liberal and Marxist approaches is the leitmotif of this period. The advocates of the liberal approach argued that informal settlements were not a problem, rather they were a tool for solving the housing crisis in the cities of developing countries; such advocates also promoted a romantic image of squatter-landowners. The advocates of the Marxist approach, on the other hand, considered squatters as potential revolutionaries. During the third period (1980s-present) a lot of romantic views of squatter settlements were reconsidered. This period is characterized by conceptual pluralism. Although research on squatter settlements in post-Soviet cities is relatively young compared to the research in other developing countries, it has much to offer in terms of the concepts applied and the results obtained. Four key topics in the research on post-Soviet informal settlements can be identified: 1) the strategies of property acquisition in informal settlements; 2) the relationships between legal citizens and the dwellers of informal settlements; 3 ) the strategies of social and economical adaptation of rural migrants living in squatter settlements; 4) the relationships of the dwellers of informal settlements with the state and other political actors.
\end{abstract}

Key words: squatter settlements, informal settlements, rural migrants, urbanization, rural to urban migration, post-Soviet city 


\section{References}

Alekseeva M.S. (2010) Selsko-gorodskaya migratsiya i problema samovolnykh poselenij v postsovetskoj Buryatii: sotsialno-ekologicheskij podkhod [Rural to Urban Migration and the Problem of Squatter Settlements in Post-Soviet Buryatia]. Zhurnal sotsiologii $i$ sotsialnoj antropologii, vol. 13, pp. 128-129.

Alymbaeva A. (2013) Internal Migration in Kyrgyzstan: A Geographical and Sociological Study of Rural Migration. Migration and Social Upheaval as the Face of Globalization in Central Asia (ed. Laruelle M.), Boston: Brill, pp. 117-148.

Amis P. (1984) Squatters or Tenants: the Commercialization of Unauthorized Housing in Nairobi. World Development, vol. 12, no 1, pp. 87-96.

Arutyunyan Yu.V., Drobizheva L.M., Susokolov A.A. (1999) Etnosotsiologiya [Ethnosociology], Moscow: Aspekt-Press.

Balaban U. (2011) The Enclosure of Urban Space and Consolidation of the Capitalist Land Regime in Turkish Cities. Urban Studies, vol. 48, no 10, pp. 2162-2179.

Batomunkuev S.D. (2005) Etnicheskaya identichnost' v usloviyakh postsovetskogo Ulan-Ude [Ethnic Identity in the Context of Post-Soviet Ulan-Ude]. Bajkal, special issue, pp. 146-151.

Berner E. (1997) Defending a Place in the City: Localities and the Struggle for Urban Land in Metro Manila, Quezon City: Ateneo de Manila University Press.

Berner E. (2002) Learning from Informal Markets: Innovative Approaches to Land and Housing Provision. Development and Cities: Essays from Development in Practice (eds. Westendorff D., Eade D.), Oxford, pp. 226-247.

Bogomolov A.V., Danilov C.I., Semivolos I.N. (2012) Zemelnye spory kak factor sotsialnykh konfliktov v Krymu [Land Disputes as a Factor of Social Conflicts in Crimea]. Skhidnij svit, no 4, pp. 164-188.

Bon T.M. (2013) «Minskijfenomen». Gorodskoe planirovanie i urbanizatsiya v Sovetskom Soyuze posle Vtoroj mirovoj vojny ["The Minsk Phenomenon". Urban Planning and Urbanization in the Soviet Union after World War II], Moscow: ROSSPEN.

Breslavsky A. (2014) Nezaplanirovannye prigorody: selsko-gorodskaya migratsiya i rost UlanUde v postsovetskij period. [Unplanned Suburbs: Rural to Urban Migration and the Growth of Ulan-Ude], Ulan-Ude: BSC SB RAS Press.

Burcev A.G. (2014) Samodeyatel'noe stroitel'stvo zhil'ya v Sverdlovske 1924-1925 gg. Kooperatsiya I chastniki [Self-help Housing in Sverdlovsk 1924-1925. Cooperation and Private Builders]. Arkhitekton: izvestiya vuzov, no 48. Available at: http://archvuz.ru/2014_4/10, accesses 31 October 2017.

Burgess R. (1977) Self-help Housing: A New Imperialist Strategy? A Critique of the Turner School. Antipode, vol. 9, no 2, pp. 50-59.

Burgess R. (1978) Petty Commodity Housing or Dweller Control? A Critique of John Turner's Views on Housing Policy. World Development, vol. 6, no 9, pp. 1105-1133.

Castells M. (1983) The City and the Grassroots: a Cross-Cultural Theory of Urban Social Movements, University of California Press.

Collier D. (1976) Squatters and Oligarchs: Authoritarian Rule and Policy Change in Peru, Baltimore: The Johns Hopkins University Press.

Cornelius W.A. (1977) The Political Sociology of Cityward Migration in Latin America: Toward Empirical Theory. Third World Urbanization (eds. Abu-Lughod J., Hay JR.R), New York, London, Toronto: Methuen, pp. 213-224.

Costello M.A. (1987) Slums and Squatter Areas as Entrepots for Rural-Urban Migrants in a Less Developed Society // Social Forces, vol. 66, no 2, pp. 427-445.

Davis M. (2006) Planet of Slums, London \& New York: Verso.

Davydov V.N., Karbainov N.I., Simonova V.V., Chelishcheva V.G. (2006) Aginskaya street tanets s ognem i alyuminievye strely prisvoenie kulturnykh landshaftov [Aginskaya Street, Fire Dance and Aluminum Arrows: the Appropriation of Cultural Landscapes], Khabarovsk: Habarovsk Scientific Center FAB RAS. 
De Soto H. (1989) The Other Path: The Invisible Revolution in the Third World, New York: Basic Books.

Demirtaş N. (2009) Social Spatialization in a Turkish Squatter Settlements: Dualism Strategy and Tactic Reconsidered, Frankfurt am Main: Peter Lang GmbH.

Dobretsova N.N. (2006) Ruralizaciya i pogloshchenie gorodskoj subkultury [Ruralisation and Absorption Urban Subculture]. EKO, vol. 9, pp. 116-130.

Eckstein S. (1990) Urbanization Revisited: Inner-city Slum of Hope and Squatter Settlement of Despair. World Development, vol. 18, no 2, pp. 165-181.

Emelyanov D.N. (2015) Zemelnye otnosheniya v sovremennom Krymu [Land Relations in Crimea]. Vestnik RGAU, no 1 (25), pp. 85-89.

Erman T. (2001) The Politics of Squatter (gecekondu) Studies in Turkey: the Changing Representations of Rural Migrants in the Academic Discourse. Urban Studies, vol. 38, no 7, pp. 983-1002.

Fedorov A. (2010) «Rechnik» eto «nakhalovka» [«Rechnik» is a «nakhalovka»]. Moskovskij Komsomolets. Available at: http://www.mk.ru/social/article/2010/06/20/510996-rechniketo-nahalovka.html, accesses 31 October 2017.

Fryer P., Nasritdinov E., Satybaldieva E. (2014) Moving Toward the Brink? Migration in the Kyrgyz Republic. Central Asian Affairs, vol. 1, no 2, pp. 171-198.

Gilbert A. (1983) The Tenants of Self-Help Housing: Choice and Constraint in the Housing Markets of Less Developed Countries. Development and Change, vol. 14, no 3, pp. 449-477.

Gilbert A.G., Ward P.M. (1982) Residential Movement Among the Poor: the Constraints on Housing Choice in Latin American Cities. Transactions of the Institute of British Geographers, vol. 7, no 2, pp. 129-149.

Gilbert A., Ward P.M. (1985) Housing, the State, and the Poor: Policy and Practice in Three Latin American Cities, Cambridge University Press.

Gilko M.A. (2011) Transsibirskaya magistral' i problemy gorodskogo khozyajstva dorevolyutsionnogo Krasnoyarska [Trans-Siberian Railway and the Problems of Urban Economy in Pre-revolutionary Krasnoyarsk]. Vestnik KrasGAU, vol. 12, pp. 256-263.

Gnedinskaya A. (2016) Snos domov v Plekhanovo tsygane nazvali strashnym dnem tabora [Gypsies Characterize the Demolition of Houses in Plekhanovo as an Apocalypse for their People]. Moskovskij Komsomolets. Available at: http://www.mk.ru/social/2016/05/30/snos-domov-vplekhanovo-cygane-nazvali-strashnym-dnem-tabora.html, accesses 31 October 2017.

Handelman H. (1975) The Political Mobilization of Urban Squatter Settlements. Santiago's Recent Experience and Its Implications for Urban Research. Latin American Research Review, vol. 10, no 2, pp. 35-72.

Harris R. (2014) Urban Land Markets: a Southern Exposure. The Routledge Handbook on Cities of the Global South (eds. Parnell S., Oldfield S.), New York: Routledge.

Humphrey C. (2010) Post-sovetskie transformatsii v aziatskoj chaste Rossii: antropologicheskie ocherki [Post-Soviet Transformations in Asiatic Russia. Anthropological Studies], Moscow: Natalis.

Hushzermeyer M. (2004) Unlawful Occupation: Informal Settlements and Urban Policy in South Africa and Brazil, Trenton, NJ: Africa World Press.

Isabaeva E. (2014) From Denizens to Citizens in Bishkek: Informal Squatter-Settlement Residents in Urban Kyrgyzstan. The Journal of Social Policy Studies, no 2, pp. 249-260.

Karbainov N.I. (2004) «Gorodskie» i «golovary» v Ulan-Ude (molodyozhnye subkultury v borbe za sotsial'noe prostranstvo goroda) [The "Townsmen" and the "Golovary" in Ulan-Ude: Youth Subcultures in the Struggle for Urban Social Space]. Vestnik Evrazii, no 2, pp. 170-183.

Karbainov N.I. (2007) «Nakhalovki» Ulan-Ude: «ogorazhivanie» prigorodnoj zemli ["Nakhalovki" of Ulan-Ude: "Inclosure" of Suburban Territory]. Sotsiologicheskie issledovaniya, no 11, pp. 136-139.

Karbainov N.I. (2010) Strategii obosnovaniya prav sobstvennosti na zemlyu v situatsii pravovogo plyuralizma (na primere zemelnykh sporov v gorode Ulan-Ude) [The Strategies of Property Rights' Justification in the Context of Legal Pluralism]. Zhurnal sotsiologii $i$ sotsial'noj antropologii, vol. 13, no 4, pp. 140-157.

Karbainov N.I. (2014) Kak vladeltsy ne stanovyatsya chastnymi sobstvennikami na primere zemelnykh konfliktov v Ulan-Ude i Sochi [How Owners (do not) Become Private 
Proprietors: Land Conflicts in Ulan-Ude and Sochi]. Zhurnal sotsiologii i sotsial'noj antropologii, vol. 17, no 5, pp. 85-108.

Karpat K.H. (1976) The Gecekondu: Rural Migration and Urbanization, Cambridge: Cambridge University Press.

Kosmarskaya N.P. (2011) «Ponaekhali tut po-bishkekski ...»: migrant i starozhily v gorode kak zerkalo kirgizskoj revolyutsii. Antropologiya sotsialnykh izmenenij. Issledovaniya po sotsial'no kulturnoj antropologii [Interlopers a la Bishkek ...»: Migrants and Old Residents in City as Mirror of Kyrgyz Revolution] (eds. Guchinova E.-B., Komarova G.), Moscow: ROSSPEN, pp. 595-614.

Kostyukova I. (1994) The Towns of Kyrgyzstan Change Their Faces: Rural-urban Migrants in Bishkek. Central Asian Survey, vol. 13, no 3, pp. 425-434.

Kozhakhmetov A., Asanbaev M. (2010) Vnutrennyaya migratsiya v Kazakhstane: v poiskakh resheniya [Internal Migration in Kazakhstan: a Search for Solutions], Almaty: ROO «Shanyrak».

Kumar S. (1996) Subsistence and Petty Capitalist Landlords: a Theoretical Framework for the Analysis of Landlordism in Third World Urban Low Income Settlements. International Journal of Urban and Regional Research, vol. 20, no 2, pp. 317-329.

Lloyd P. (1979) Slums of Hope?: Shanty Town of the Third World, Manchester: Manchester University Press.

Lomnitz L.A. (1977) Networks and Marginality: Life in a Mexican Shantytown, New York: Academic Press.

Losevskaya O.D. (2014) Istoriya poyavleniya depressivnykh prostranstv v tsentral'noj chasti g. Novosibirska [The History of Depressive Locations in the Central Part of Novosibirsk]. Balandinskie Chteniya, vol. 9, no 2, pp. 231-237.

Mangin W. (1967) Latin American Squatter Settlements: A Problem and a Solution. Latin American Research Review, vol. 2, no 3, pp. 65-98.

Manzanova G. (2007) City of Migrants: Contemporary Ulan-Ude in the Context of Russian Migration. Urban Life in Post-Soviet Asia (eds. Alexander C., Buchli V., Humphrey C.), University College London Press, pp. 125-135.

Marcuse P. (1996) Privatization and its Discontents: Property Rights in Land and Housing in the Transition in Eastern Europe. Cities after Socialism: Urban and Regional Change and Conflict in Post-Socialist Societies (eds. Andrusz G., Harloe M., Szelenyi I.), Oxford: Blackwell Publisher, pp. 119-191.

Mikhalev A.V. (2008) Konstruirovanie traditsionnosti v prostranstve samostroya sovremennogo Ulan-Ude: etnograficheskij ocherk [The Construction of Traditionality in the Samostroy Area of Contemporary Ulan-Ude: an Ethnographical Review]. Izvestiya Altajskogo Gosudarstvennogo universiteta, vol. 4-5, pp. 142-145.

Nasritdinov E., Zhumakadyr kyzy B., Asanalieva D. (2015) Myths and Realities of Bishkek's Novostroikas. Kyrgyzstan beyond 'Democracy Island'and 'Failing State': Factoring Social and Political Challenges in a Post-Soviet Society (eds. Laruelle M., Engvall J.), Lanham: Lexington Books, pp. 145-163.

Peattie L., Aldrete-Haas J.A. (1981) "Marginal" Settlements in Developing Countries: Research, Advocacy of Policy, and Evolution of Programs. Annual Review of Sociology, vol. 7, pp. $157-175$.

Perlman J. (1976) The Myth of Marginality: Urban Poverty and Politics in Rio de Janeiro, Berkeley: University of California Press.

Potter R., Lloyd-Evans S. (1998) The City in the Developing World, Singapore: Longman.

Rumyantsev S. (2008) Neft' i ovtsy: iz istorii transformatsij goroda Baku iz stolitsy v stolitsu. P.S. Landshafty: optiki gorodskikh issledovanij [Oil and Sheeps: History of Urban Transformation in Baku from Capital to Capital] (eds. Milerius N., Cope B.), Vilnius: EGU, pp. 228-266.

Sanghera B., Satybaldieva E. (2012) Ethics of Property, Illegal Settlements and the Right to Subsistence. International Journal of Sociology and Social Policy, vol. 32, no 1-2, pp. 96-114.

Sanghera B., Satybaldieva E., Rodionov A., Serikzhanova S., Choibekov N., Sultanmuratova K. (2012) Illegal Settlements and City Registration in Kyrgyzstan and Kazakhstan: Implications for Legal Empowerment, Politics and Ethnic Tensions. Central Eurasia Project, New York: Open Society Foundations. 
Seleev S.S. Pavlov A.B. (2016) Garazhniki [Garazhniki], Moscow: Strana OZ.

Shvets A.B. (2008) Pasportizatsiya sotsiokulturnykh protivorechij v Krymu [Passportization of Sociocultural Contradictions in Crimea]. Geopolitika i ekogeodinamika regionov, vol. 4, no $1-2$, pp. $72-79$.

Smart A. (1986) Invisible Real Estate: Investigations into the Squatter Property Market. International Journal of Urban and Regional Research, vol. 10, no 1, pp. 29-45.

Snyder P. (1976) Neighborhood Gatekeepers in the Process of Urban Adaptation: Cross-ethnic Commonalities. Urban Anthropology, vol. 5, no 1, pp. 35-52.

Sodnompilova M.M.(2009) Selsko-gorodskaya migratsiya v Buryatii: formirovanie translokalnogo soobshchestva. Gorod i selo v postsovetskoj Buryatii. Sotsial'no-antropologicheskie ocherki [Rural to Urban Migration in Buryatia: Formation of Trans-local Space] (ed. Skrynnikova T.D.), Ulan-Ude: BSC SB RAS Press, pp. 165-186.

Stokes Ch. (1962) A Theory of Slums. Land Economics, vol. 38, no 3, pp. 187-197.

Tsenkova S. (2012) Urban Planning and Informal Cities in Southeast Europe. Journal of Architectural and Planning Research, vol. 29, no 4, pp. 292-305.

Tsenkova S., Potsiou C., Badyina A. (2009) Self-made Cities: In Search of Sustainable Solutions for Informal Settlements in the United Nations Economic Commission for Europe Region, New York and Geneva: United Nations Publications.

Turner J. (1968) Uncontrolled Urban Settlement: Problems and Policies. International Social Development Review, no 1, pp. 107-128.

Turner J. (1996) From Housing to Building Community. City: Analysis of Urban Trends, Culture, Theory, Policy, Action, vol. 1, no 3-4, pp. 30-39.

Uehling G.L. (2004) Beyond Memory: The Crimean Tatars'Deportation and Return, New York: Palgrave Macmillan.

Yessenova S. (2010) Borrowed Places: Eviction Wars and Property Rights Formalization in Kazakhstan. Economic Action in Theory and Practice: Anthropological Investigations (ed. Wood D.C.), Bingley: Emerald, pp. 11-46.

Zhimbiev B. (2000) History of the Urbanization of a Siberian City: Ulan-Ude, London: The White Horse Press.

Zhumakadyr kyzy B. (2012) Development in Urbanized Settings: A Study of Novostroikas in Bishkek. Unpublished Bachelor's thesis, American University of Central Asia, Bishkek. 